\title{
Resilience, political ecology, and well-being: an interdisciplinary approach to understanding social-ecological change in coastal Bangladesh
}

\author{
$\underline{\text { Sonia F. Hoque }}^{1}$, Claire H. Quinn ${ }^{1}$ and Susannah M. Sallu ${ }^{1}$
}

\begin{abstract}
The commodification of peasant livelihoods through export-oriented aquaculture has brought about significant socialecological changes in low-lying coastal areas in many parts of Asia. A better understanding of the underlying drivers and distributional effects of these changes requires integration of social and ecological approaches that often have different epistemological origins. Resilience thinking has gained increased traction in social-ecological systems research because it provides a dynamic analysis of the cross-scalar interactions between multiple conditions and processes. However, the system-oriented perspective inherent in resilience thinking fails to acknowledge the heterogeneous values, interests, and power of social actors and their roles in navigating social-ecological change. Incorporation of political ecology and well-being perspectives can provide an actor-oriented analysis of the trade-offs associated with change and help to determine which state is desirable for whom. However, empirical demonstrations of such interdisciplinary approaches remain scarce. Here, we explore the combined application of resilience, political ecology, and well-being in investigating the root causes of social-ecological change and identifying the winners and losers of system transformation through empirical analysis of the differential changes in farming systems in two villages in coastal Bangladesh. Using the adaptive cycle as a structuring model, we examine the evolution of the shrimp aquaculture system over the past few decades, particularly looking at the power dynamics between households of different wealth classes. We found that although asymmetric land ownership and political ties enabled the wealthier households to reach their desired farming system in one village, social resilience achieved through memory, leadership, and crisis empowered poorer households to exercise their agency in another village. Material dimensions such as improved living standards, food security, and cash incomes were evidently important; however, freedom to pursue desired livelihood activities, better environmental quality, mental peace, and cultural identities had significant implications for relational and subjective well-being.
\end{abstract}

Key Words: adaptive cycle; desirable state; salinity; shrimp aquaculture; social-ecological system

\section{INTRODUCTION}

Social-ecological changes brought about by the rapid growth of the aquaculture industry and increased occurrence of climatic shocks and stresses have significantly modified the vulnerability contexts of low-lying coastal areas in many parts of Asia (Pokrant 2014, Orchard et al. 2016, Abdullah et al. 2017). An extensive body of empirical work has studied the vulnerabilities of households or communities to specific shocks and stresses, often providing a snapshot of a single spatial scale at a given time (Miller et al. 2010). However, the underlying drivers of social-ecological change and its differential effects on the well-being of social actors remain understudied (Tucker et al. 2015). These knowledge gaps can be attributed to a lack of communication between different disciplines, which often limits the scope of empirical work within the boundaries of a given concept (Janssen et al. 2006, Miller et al. 2010). Given the inherent complexity of social-ecological systems, a holistic, in-depth analysis of different elements within the system requires an integrative, interdisciplinary approach that bridges across several ecological and social knowledge domains (Binder et al. 2013, McGinnis and Ostrom 2014).

Since the mid-2000s, resilience has emerged as an important concept in evaluating social-ecological change because it provides a dynamic approach to system analysis and management, with emphasis on nonlinearity and multiscalar feedback mechanisms (Ingalls and Stedman 2016). Resilience thinking, however, is criticized for its system-level bias that does not account for the role of power dynamics in navigating social-ecological change and the distribution of costs and benefits associated with change (Cote and Nightingale 2012, Fabinyi et al. 2014, Brown 2016). As such, several authors have highlighted the potential of a political ecology perspective in analyzing the asymmetries in power (Peterson 2000, Davoudi 2012, Turner 2013) and have emphasized the need to integrate well-being approaches in addressing the differential needs and values of social actors (Coulthard et al. 2011, Armitage et al. 2012, Coulthard 2012).

Despite theoretical progress, only a few empirical studies have combined resilience thinking with political ecology (e.g., BeymerFarris et al. 2012, Moshy et al. 2015) or human well-being (e.g., Marschke and Berkes 2006, Moshy et al. 2015) to analyze the politics of desirable states, the trade-offs associated with adaptation strategies, and the winners and losers of change. Here, we aim to explore empirically the combined application of resilience, political ecology, and well-being perspectives in understanding the drivers and distributional effects of socialecological change in coastal Bangladesh. In doing so, we compare the cases of two villages that had similar levels of exposure to natural shocks and stresses but experienced differential changes in farming systems. We use the resilience concept to describe the nature of the changes in relation to the system characteristics and functions and apply a political ecology lens to examine the roles of different actors in shaping the trajectories of change. We then analyze the implications of these changes for the well-being of actors with heterogeneous interests and needs. We first briefly review the theoretical literature on resilience, political ecology,

\footnotetext{
${ }^{1}$ Sustainability Research Institute, School of Earth and Environment, University of Leeds
} 
and well-being and highlight the need for overcoming disciplinary boundaries to better theorize the social dimensions of socialecological resilience.

\section{LITERATURE REVIEW}

Resilience thinking has captured interest in environmental social science research by analyzing human-nature interactions in the face of global environmental change (Leach 2008, Speranza et al. 2014). Originating from the ecological sciences, resilience embraces change as an inevitable feature of a system and places emphasis on either maintaining its character by absorbing the disturbance or transforming to a new regime when conditions become untenable (Walker et al. 2004, Folke 2006). Although early definitions of social-ecological resilience mainly focused on a system's post-event buffer capacity (Adger 2000, Walker et al. 2004), social scientists later expanded the concept to include the capacity of actors to learn from experience and build knowledge and skills for transformation (Folke 2006, Cutter et al. 2008). The adaptive renewal cycle, a heuristic model within resilience thinking, suggests that all complex systems, whether natural ecosystems or human societies, undergo cyclic changes comprised of exploitation (r), conservation (K), release $(\Omega)$ and reorganization $(\alpha)$ phases (Holling 1986, Gunderson and Holling 2002). As a system passes through these four phases, its resource use and structure gradually increases until it becomes so rigid that a disturbance leads to a chaotic collapse followed by a new growth phase characterized by innovation and experimentation (Holling 2001, Folke 2006). The dynamics of a system at a certain scale are influenced by the slow- and fast-moving variables at higher and lower scales, creating a hierarchy of nested sets of adaptive cycles, referred to as panarchy (Gunderson and Holling 2002).

Resilience thinking is often criticized for its system-oriented approach, which puts little emphasis on the entities that comprise a system unless they are captured within the system's structure (Turner 2013). It tends to homogenize social complexity and assume that all actors within the system have similar interests, expectations, and behavior (Fabinyi et al. 2014). The process of building resilience, either though incremental adjustments or through radical transformations, often creates new patterns of winners and losers because certain system regimes may be considered more desirable by one segment of society than another (Walker and Salt 2006). Academic literature in the field to date has insufficiently addressed the basic issues of power, politics, and agency, as well as debates over fundamental questions such as "What is desirable?" and "For whom?" (Cote and Nightingale 2012, Davoudi 2012). To understand the drivers and differential effects of social-ecological change, there is a need to account for the different perspectives and desired states of the people involved (Cote and Nightingale 2012, Fabinyi et al. 2014) and consider inequities in decision-making procedures and the distribution of costs and benefits resulting from change (Davoudi 2012). This has led to increased calls for bringing in insights from political ecology, which would enable resilience studies to engage sufficiently with power dynamics among social actors (Peterson 2000, Beymer-Farris et al. 2012, Cote and Nightingale 2012, Turner 2013, Fabinyi et al. 2014, Brown 2016, Ingalls and Stedman 2016).

A political ecology approach highlights how power relations influence the access, control, and management of resources and places politics at the forefront of analysis to identify social origins of environmental degradation and the plurality of perceptions (Peet and Watts 1996, Bryant 1998). Contentions among social and political scientists have generated various perspectives of power. Power involves the ability of an actor within a social relation to carry out his or her own will despite resistance from others (Weber 1947, Dahl 1957), to set the agenda or prevent the discussion of controversial issues (Bachrach and Baratz 1962), and to shape others' perceptions and preferences in ways that cause them to act contrary to their own interests (Lukes 1974). Applying these three dimensions of power to study complex social-ecological interactions is, however, complicated because it is unfeasible to attribute causal relationships between individual actions and undesirable collective outcomes (Olsson et al. 2014, Boonstra 2016). To address these challenges, it is necessary to identify the availability, distribution, and mobilization of various sources of power and conceptualize power both as a "conduct shaping" and a "context shaping" force (Boonstra 2016). Recognizing the indirect consequences of human behavior on social structures and events that influence the conditions for subsequent actions can facilitate the integration of power in resilience studies (Boonstra 2016).

Asymmetries in social power can shape social-ecological change in ways in which the interests of some actors are privileged over others, thus involving trade-offs and creating distributional inequities (Ingalls and Stedman 2016). Human well-being has emerged as an important concept within the literature on resilience and ecosystem services as a means to analyze the heterogeneous needs of different social groups and identify the winners and losers of change (Coulthard et al. 2011, Daw et al. 2011, 2015, Armitage et al. 2012, Coulthard 2012, Hossain et al. 2017). Well-being is defined as "a state of being with others, where human needs are met, where one can act meaningfully to pursue one's goals, and where one enjoys a satisfactory quality of life" (Wellbeing in Developing Countries Research 2007:1). It is a three-dimensional concept comprising what people have (the material dimension such as food, shelter, health, assets, and standard of living), what they can do with what they have (the relational dimension, including personal relationships, networks of support and obligations, cultural identities, inequalities and conflict, and scope for personal and collective action), and how they think about what they have and can do (the subjective dimension, involving life satisfaction, fears and aspirations, trust and confidence, and sense of meaning; McGregor 2007, Copestake 2008, White 2010).

Understanding the drivers and distributional effects of socialecological change through the combined application of resilience, political ecology, and well-being perspectives entails incorporation of social stratifiers as a means of disaggregating different social groups. We use household poverty level (alternatively referred to as wealth class) as a central lens for differentiation, whereby poverty is assessed from a multidimensional approach involving a wide range of context-relevant indicators. We next describe the research methods and study sites. Empirical evidence from the study sites is then presented, followed by a discussion about how an interdisciplinary approach can greatly enhance our understanding of the complex processes and outcomes of socialecological change. 
Table 1. Description of research tools used for data collection and participant selection methods.

\begin{tabular}{|c|c|c|}
\hline Research tool & Description & Participants \\
\hline $\begin{array}{l}\text { Focus group } \\
\text { discussion }\end{array}$ & $\begin{array}{l}\text { Overview of changes in livelihoods over the previous four } \\
\text { decades, with detailed discussion of the underlying causes } \\
\text { and effects of these changes on different groups }\end{array}$ & $\begin{array}{l}\text { Two separate male and female focus group discussions in each } \\
\text { village, with each discussion involving } 8-10 \text { adult participants from } \\
\text { different wealth classes }\end{array}$ \\
\hline $\begin{array}{l}\text { Participatory wealth } \\
\text { ranking }\end{array}$ & $\begin{array}{l}\text { Identification of the number of wealth classes within the } \\
\text { village and the core characteristics that differentiate one } \\
\text { class from another }\end{array}$ & $\begin{array}{l}\text { Group of 3-4 key informants such as school teachers, local } \\
\text { government members, and mosque leaders, who have good } \\
\text { knowledge of the wealth distribution within the village }\end{array}$ \\
\hline $\begin{array}{l}\text { Household } \\
\text { questionnaire survey }\end{array}$ & $\begin{array}{l}\text { Semistructured questionnaire to collect quantitative data } \\
\text { on households' demographic profile, asset ownership, } \\
\text { livelihood activities, perceptions of brackish-water shrimp } \\
\text { farming, and changes in well-being }\end{array}$ & $\begin{array}{l}150 \text { households ( } 25 \% \text { of approximately } 600 \text { households) in each } \\
\text { village, selected through a random route sampling method; each of } \\
\text { the villages was divided into neighborhoods, and households were } \\
\text { selected within each neighborhood via a "random walk." } \\
\text { Household heads were the primary respondents; however, } \\
\text { participation from any willing household member was welcomed to } \\
\text { obtain more accurate data }\end{array}$ \\
\hline $\begin{array}{l}\text { Livelihood trajectory } \\
\text { interview }\end{array}$ & $\begin{array}{l}\text { Unstructured interviews to generate qualitative data on } \\
\text { changes in assets, livelihood strategies, and well-being over } \\
\text { the previous decades, with detailed exploration of the } \\
\text { underlying causes of these changes }\end{array}$ & $\begin{array}{l}25 \text { interviews in each village with adult males and females selected } \\
\text { through a purposive sampling method, ensuring representation } \\
\text { from all wealth classes and different occupations }\end{array}$ \\
\hline
\end{tabular}

\section{RESEARCH METHODS}

A mixed-method approach comprising of focus group discussions (FGDs), participatory wealth ranking (PWR), household questionnaire surveys, and livelihood trajectory interviews was used to collect empirical evidence in late 2014 (Table 1). Data from PWR and household surveys were used to stratify households by wealth class. Understanding the drivers of social-ecological change involved the analysis of qualitative data from FGDs and interviews in relation to the characteristics of the adaptive cycle, whereas assessments of well-being impacts were based on both survey and interview data.

PWR was used to identify the number of wealth classes within each village and outline the main characteristics that differentiate one class from another. Coincidentally, participants in both villages disaggregated households into five wealth categories, namely, rich, upper middle, lower middle, poor, and extreme poor, using agricultural land ownership as the most important determinant along with indicators such as relative income, housing materials, education, and food security (refer to Table A1.1 in Appendix 1 for details). Asset ownership data from household surveys were used to generate household wealth indices and calculate the numbers of sample households belonging to each of the five categories (Table A1.2 in Appendix 1). Principal component analysis (PCA) was carried out using 17 indicators under seven dimensions (refer to Table A1.3 in Appendix 1 for descriptive statistics). All components with an eigenvalue $>1$ were extracted, of which the factor scores and factor loadings of the first principal component (PC1) were considered as the household wealth indices and indicator weights, respectively (Table A1.4 in Appendix 1). K-means cluster analysis with five clusters was then applied on the $\mathrm{PC} 1$ factor scores to quantitatively disaggregate households into five wealth classes. PCA also revealed the variation in asset ownership within and between different classes and inequality in wealth distribution within the two communities (refer to Tables A1.5 and A1.6 in Appendix 1 for details on asset ownership).

Following translation and transcription, qualitative data from FGDs and livelihood trajectories were scrutinized, and chunks of text related to historical events were coded as per the spatial scale (international, national, regional, or local) and the domain in which they occurred (socio-political, agro-ecological, or economic). The events closely adhered to the characteristics defining each of the four phases of the adaptive cycle in terms of the system's potential (that is, the wealth of the system) and connectedness (that is, the internal controllability of the system; refer to Table A1.7 in Appendix 1 for details of data analysis). The events were then arranged chronologically, demarcating boundaries between the phases for the two villages respectively. Although this demarcation aided structuring and analysis of data, it should be noted that these boundaries are highly flexible and represent broader time periods instead of rigid start and end dates.

Quantitative data from household surveys were used to construct bar charts on households' changes in well-being resulting from the changes in farming systems. The questionnaire included an open-ended question asking respondents whether they were better off, worse off, or same as before, and why. Using this subjective line of inquiry resulted in a wide range of responses in which relational factors such as having a peaceful community often emerged in addition to the usual objective factors such as income and assets. These were also supplemented with qualitative data from interviews that provided deeper insights into individuals' values, struggles, and aspirations. Individuals' responses may not be representative of all members within the household; however, because we primarily focused on understanding the power dynamics between different wealth classes, intrahousehold differences and gender dimensions were not studied.

\section{STUDY SITES}

The study villages, Mithakhali and Kamarkhola, are located in southwestern coastal Bangladesh (Fig. 1), an active deltaic floodplain characterized by high vulnerability to salinity intrusion and cyclones accompanied by tidal surges (Shameem et al. 2014, Huq et al. 2015). Salinity intrusion is largely a seasonal phenomenon; changes in upstream river flows lead to a relatively freshwater regime during the wet season and high levels of water and soil salinity during the dry season (Nuruzzaman 2006). However, this natural process has been exacerbated by the construction of the Farakka dam on the Ganges River in India, 
Fig. 1. Map of Bangladesh showing the locations of the two study sites.

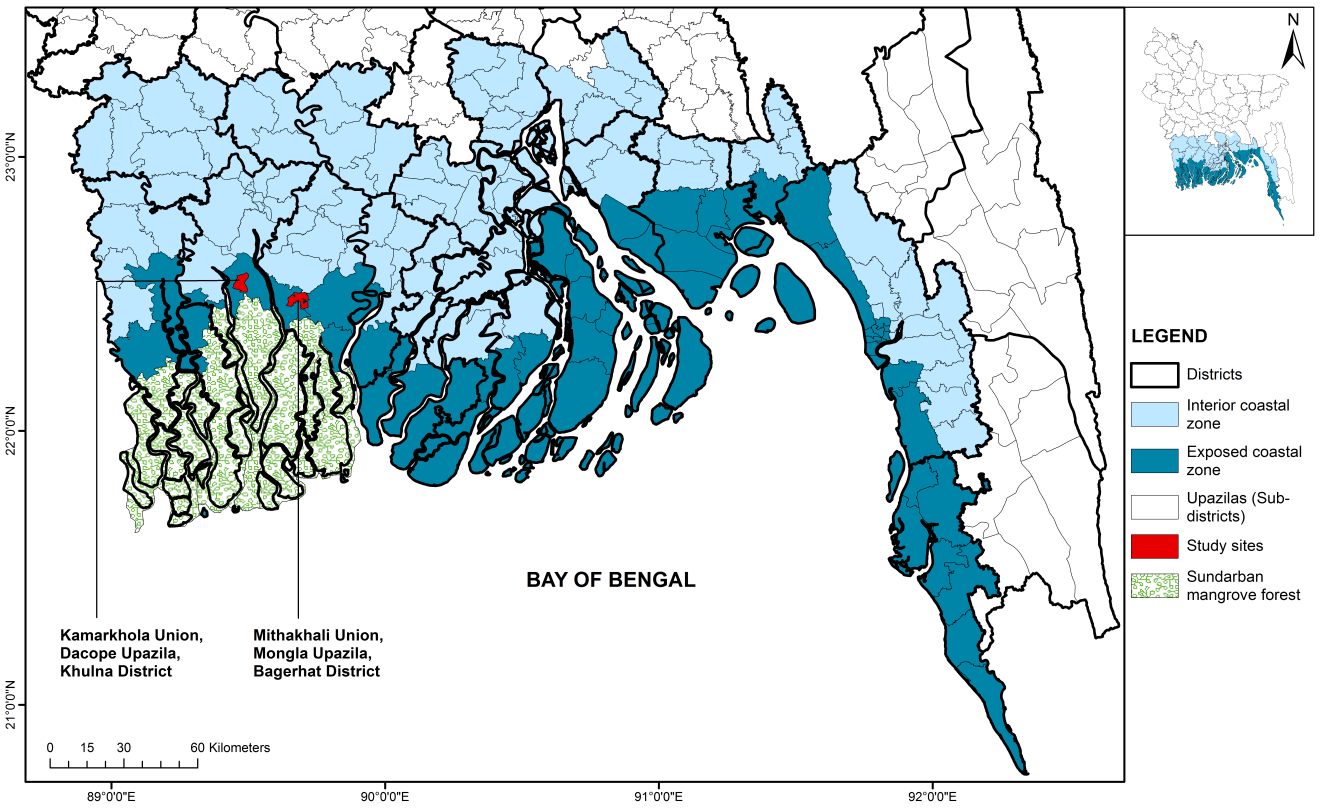

the establishment of hundreds of coastal embankments in Bangladesh, and the growth of brackish water shrimp farming since the 1970s (Mahmuduzzaman et al. 2014, Pokrant 2014). The funnel-shaped configuration of the coastline provides a breeding ground for cyclones, which generally strike in late May or early November (Ministry of Environment and Forests 2009). Two of the most recent events, the 2007 cyclone Sidr and the 2009 cyclone Aila, had devastating effects on coastal communities, with Kamarkhola being one of the four worst affected places (Disaster Management Bureau 2010).

While both villages traditionally depended on paddy cultivation during the wet season (July-December), a number of agroecological, socioeconomic, and political factors caused a twostage change in the farming systems since the 1980s (Fig. 2). In the first stage, brackish water shrimp cultivation (Penaeus monodon, locally known as Bagda) was introduced during the dry season (February-June), along with wet season paddy in both villages. In the second stage, the two villages embarked on different trajectories, with Mithakhali phasing out paddy gradually and replacing it with freshwater whitefish farming, and Kamarkhola banning shrimp cultivation and reverting to traditional subsistence-based paddy farming along with freshwater prawn (Macrobrachium rosenbergii, locally known as Galda) and whitefish. The underlying causes of these differential changes in farming systems and their implications for human wellbeing are discussed next.

\section{RESULTS}

\section{Drivers of social-ecological change}

\section{Exploitation and conservation phases in both Mithakhali and} Kamarkhola

Fig. 3 illustrates the chronology of events at different spatial scales during the four phases of the adaptive cycle. The exploitation and conservation phases were similar for both villages, as well as the
Fig. 2. Changes in farming systems in Mithakhali and Kamarkhola.

Both Mithakhali and Kamarkhola Before shrimp cultivation started (1980s and before)

Aman paddy (Local varieties) 1.2 tonnes per acre)

Mithakhali: Shrimp and paddy cultivation (1990s - mid-2000s)

Kamarkhola: Shrimp and paddy cultivation (1990s - 2008)

\section{Brackish water Bagda shrimp}

Aman paddy (Local varieties)

Mithakhali: After rice cultivation was stopped (mid-2000s to present)

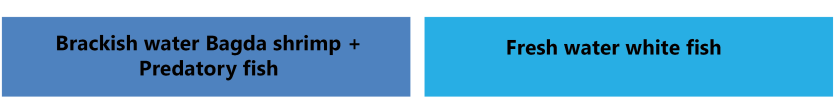

Kamarkhola: After shrimp cultivation was banned (2009 - present)

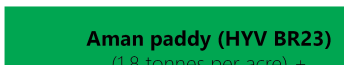

White fish \& Galda prawn

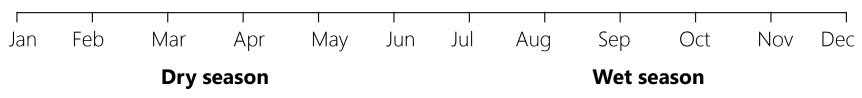

south-western coastal region in general. During the 1960s and early 1970s, the government implemented the "Coastal Embankment Project," under which hundreds of polders were constructed in the coastal region of Bangladesh to increase wet season agricultural productivity by keeping out saline water. From the late 1970s, increased international market demand and high prices for shrimp spurred an interest among farmers in shrimp aquaculture, causing agricultural lands to be turned into shrimp 
Fig. 3. Timeline of events characterizing the four phases of the adaptive cycle in Mithakhali and Kamarkhola.

\section{A. Exploitation and conservation phases}

International

National

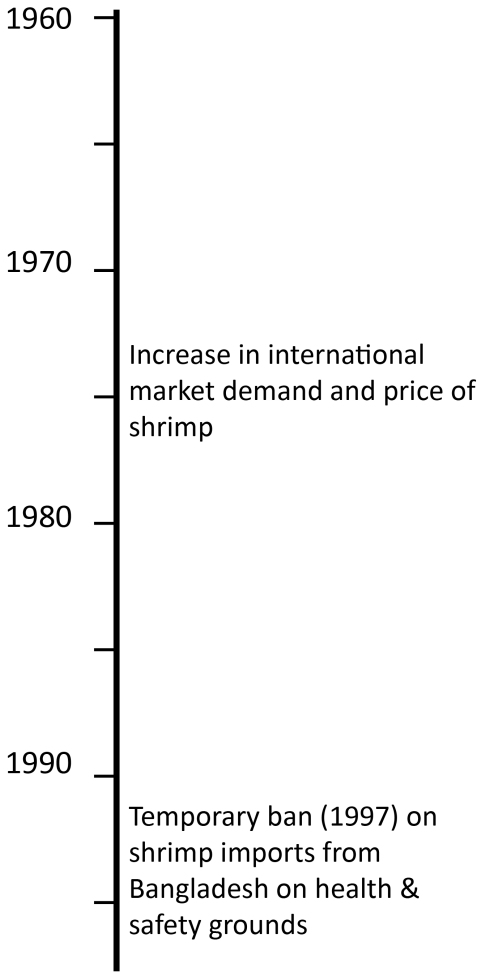

\section{Southwestern coastal region}

Coastal embankment project to increase agricultural productivity by preventing saline water entry

Bangladesh gained independence from Pakistan (1971)

Structural adjustment program to promote export oriented market-based national economic growth (1979 - 96)

Growth in shrimp industry increasing national revenue and employment opportunities
Extensive shrimp cultivation using natural post-larvae from mangroves
Land grabbing by outside entrepreneurs with strong political affiliation

Rising social tensions among local farmers and outside entrpreneurs leading to a number of violent protests

Shift towards improved extensive methods, using hatchery-bred post-larvae Disease outbreaks leading to increased shrimp mortality and reduced profits

\section{B. Release and re-organization phases}

\section{Mithakhali}

$2000 \begin{aligned} & \text { Changes in local government (1996) facilitated } \\ & \text { exodus of outside entrepreneurs and return of } \\ & \text { shrimp farms to local landowners } \\ & \text { Increase in soil salinity led to significant decline in } \\ & \text { rice yield and vegetation cover } \\ & \text { Farmers started to phase out wet season paddy } \\ & \text { and replaced it with white fish farming }\end{aligned}$

Kamarkhola
Local farmers, supported by newly elected local government, protested against large shrimp farmers, leading to ban on shrimp cultivation (2008)

Cyclone Aila (2009) caused massive infrastructural damage; delays in embankment repair prohibited farm activities for up to two years

Institutional support in relief and rehabilitation processes, leading to improved water and sanitation facilities and greater access to credit Transformation to integrated paddy-fish farming, with experimentation with Galda prawn 
farms during the dry season. The sluice gates were kept open from February to April to allow saline water to enter farms, along with a wide variety of fish fry and natural shrimp postlarvae. Meanwhile, between 1979 and 1996, the World Bank's Structural Adjustment Programme aimed to promote the country's economic growth through the creation of an export-oriented, market-based economy. Many infrastructure development programs along with improved technology dissemination and fiscal incentives were launched to expand the shrimp industry. Apart from the expansion in the number of shrimp farms, the industry experienced concurrent growth in associated services such as hatcheries, processing plants, ice plants, and shrimp depots.

In addition to the government's role in promoting the sector, many outside entrepreneurs, including businessmen, politicians, army, and civil officials, started to invest in shrimp farming in the late 1980s. While the profits were huge, the amount of land suitable for shrimp cultivation was in short supply; hence, the appropriation of public land became a source of power play in the region. Because of interdepartment conflicts, absence of precise distribution policy, and underhanded dealings, most of the public land and canals were allocated to politically powerful persons. These outsiders also pressured local farmers to lease out their lands for shrimp farming, and in some cases, used hired musclemen to forcefully evict marginal rice farmers from their land.

\section{During the 1980s, local farmers in this area did not have much knowledge about the prospects of shrimp farming. Slowly, powerful businessmen came to this area and started to inundate our land with saline water during the dry season. The incoming water contained large quantities of wild shrimp postlarvae. The businessmen made huge profits without any investment; when they drained out the water in June, the local landowners could plant paddy. But after a few years, when rice yield started to decline, farmers wanted compensation from these businessmen, who then started paying rent. As yields continued to decline, the rents continued to increase. Participant in FGD, Mithakhali.}

During the 1990s, to increase production and cope with the decline in natural shrimp fry availability, farmers started to release hatchery-bred postlarvae, which are comparatively cheaper but more susceptible to diseases than the natural ones sold by fry collectors. In addition to Bagda shrimp, many farms also harvested large amounts of predatory fish, which entered the farms along with the tidal waters. Large-scale conversion of agricultural land to shrimp farms, deliberate flooding of rice fields and canals with saline water, and legal and illegal construction of gates and pipelines through embankments significantly increased soil and water salinity. Although the shrimp industry led to increased national income and greater employment opportunities through the establishment of associated activities, most of the income was enjoyed by a few powerful entrepreneurs. Landless farmers and sharecroppers, who traditionally leased land to grow crops, lost access to these productive resources and became unemployed.
Release and reorganization phases in Mithakhali

During the release and reorganization phases, the farming systems in the two villages followed different trajectories. Overtime, local farmers started to realize that they were deprived of the huge profits that were generated from their own land by outside entrepreneurs while also suffering from the adverse effects of shrimp cultivation, including decline in paddy yield, loss of homestead gardens, restricted access for fishing in canals, and livestock rearing. False contractual agreements, nonpayment of lease money, and disputes over common public lands led to increased social tensions. Local people were involved in street protests and violent confrontations with the outside entrepreneurs, leading to serious disruptions in law and order, violations of human rights, and even incidents of rape and murder. During the 1990s, almost all candidates of union council elections took advantage of people's sentiments and used an antishrimp position in their electoral campaigns. In Mithakhali, the locally elected lawmaker passed a law in 1996 stating jomi jar, gher tar (only the true landowner has full rights over the shrimp farms on his land). Local farmers were able to regain control over their lands and subsequently divided the large commercial farms into smaller farms managed by individual landowners.

Following the eviction of the outside entrepreneurs, local farmers in Mithakhali continued to farm brackish water shrimp along with predatory fish in the dry season, followed by paddy and small amounts of freshwater whitefish in the wet season. However, by the time the landowners gained control over their land, the "golden era" of shrimp was almost over. Prolonged shrimp farming, often supplemented with additional salts, caused the soil to lose fertility over time. Moreover, in the mid-1990s, white spot syndrome virus, believed to have originated from imported postlarvae, spread across shrimp farms and is still a major concern for farmers. Paddy yields declined considerably until costs became higher than revenue. Large farmers became reluctant to grow rice; hence, from July onward, when monsoon rains diluted the water and decreased its salinity, several species of whitefish were released onto farms. These fish were harvested in December, after which the water was drained out entirely and the land was prepared for shrimp cultivation in the following season.

\begin{abstract}
The rich people were always looking out for poor people who wanted to either lease out their land or sell it altogether. Poor people lacked foresight; they were happy with the high rent or price they were offered. They are also naïve; they never saw this much cash in hand before. Hundreds of small farms were slowly assimilated into the larger ones, making the rich more powerful. The large landowners were reluctant to drain out water from their land after the end of the dry season. And unless the large landowners removed water from their farms, the small farmers could not plant rice in the wet season. One kilogram of shrimp sold for BDT 700-800 ( 1 USD $\approx 80$ $B D T)$, whereas one maund $(37 \mathrm{~kg})$ of rice sold for $B D T$ 300; so any economically rational being would opt for aquaculture. Lower middle class farmer, Mithakhali.
\end{abstract}

The final blow came in 2007, when cyclone Sidr brought in highly saline tidal water and degraded the soil to such an extent that crop cultivation became impossible. This was followed by cyclone Aila in 2009; the tidal surge inundated the village during high tide, and 
the water receded back again on the same day during low tide. The cyclone had relatively smaller impacts in Mithakhali because it is located toward the inner part of Mongla subdistrict, further away from the main rivers. Apart from the immediate loss of fisheries and increased soil salinity in subsequent years, there was no damage to infrastructure. However, further land degradation and increased disease outbreaks had severely dwindled incomes from shrimp cultivation.

As estimated by the manager of a shrimp cooperative, shrimp mortality had increased from $5 \%$ to $80 \%$ over 15 years, and at the time of study, a farmer could still earn about BDT 42,000 per hectare (compared to BDT 340,000 per hectare in the past) during the dry season, followed by another BDT 67,000 per hectare from whitefish farming during the wet season. However, given that the mean agricultural land ownership of poor and extreme poor households, who together composed $68 \%$ of the total population, was only 0.57 and 0.016 hectares, respectively, the cash income for most people from shrimp and whitefish cultivation was very limited. Increased soil salinity and private control of water canals precluded all other sources of subsistence such as rice, vegetables, open-access fish, and livestock. Lack of funds and specialized skills constrained these households from entering other highreturn nonfarm activities. While small farmers faced food insecurity and rising debts, large farmers could still enjoy economies of scale and cope with losses by intensifying production. Thus, most households were strongly against brackish water shrimp cultivation, with some expressing ambivalent opinions. This reflected that when people internalize the harshness of their circumstances, they do not desire what they never expect to achieve. However, a limited number of households, mainly from the rich and upper middle classes, were in favor of shrimp cultivation.

The big landlords want shrimp cultivation to continue so that they can get money by sitting in Khulna city, Dhaka city, or even abroad. In a given season, they can earn up to BDT 10 million. During election time, they will be able to fund the local politicians, whereas someone like me won't be able to contribute a penny. So obviously, the politicians will support them. Those who are poor want the embankment to be built. If the embankment is there, we can keep out the saline water and use freshwater stored in canals to grow rice as well as whitefish. We can also grow winter crops like sesame and pulses. Poor farmer, Mithakhali.

In contrast, an interview with a rich farmer revealed a different perspective; he explained that although most people were against shrimp cultivation, reverting to the paddy-based system was not feasible.

I understand how decades of shrimp cultivation has adversely affected the agro-ecology of this village. But we cannot stop it at once even if we wanted to. This is something many of the farmers don't realize. If we stop shrimp cultivation today, it would take at least 3-5 years for the soil to regain its fertility. Thirty years of land degradation cannot be altered in a day. So how will these people survive in the meantime? Who will support us? Rich farmer, Mithakhali.
Release phase and reorganization phases in Kamarkhola

During the mid-1990s, in Kamarkhola, shrimp cultivation was mainly carried out by outside entrepreneurs, who leased land from local farmers in exchange of meagre rents. The success of these early entrepreneurs inspired local large landowners, who established their own independent farms or engaged in cooperative farming along with small farmers. Over time, as the adverse effects of shrimp cultivation became more apparent, people were divided over whether to continue shrimp aquaculture. Large landowners and some medium-sized ones who had gained good profits from shrimp, as well as some landless people who benefitted from working on shrimp farms, wanted to continue shrimp farming, whereas most others, especially small landowners and some large owners who faced losses from shrimp, were against it. In late 2008, residents of Kamarkhola and neighboring villages united to chase away the outside entrepreneurs when they tried to open the sluice gates in the embankment. The newly elected local parliamentary member and a couple of antisaline-water environmental protection groups played key roles in mobilizing farmers and helping them express their collective frustration against years of injustice. Finally, an order from the High Court permanently banned brackish water shrimp farming in Kamarkhola.

In mid-2009, Kamarkhola was severely affected by cyclone Aila, which caused massive infrastructural damage, displacing people to temporary settlements on the embankment and prohibiting agricultural activities for approximately 1.5 years. Despite the short-term hardships, many people referred to the event as a blessing in disguise because it brought the area into the limelight. Institutional support, in terms of relief and rehabilitation materials, enabled the people to survive during the farming system transition and led to overall infrastructural development, including better housing, water, and sanitation facilities, cyclone shelters, and embankment reinforcement. After agricultural activities resumed in 2011, most farmers obtained good yields from rice, and some used their experience from shrimp farming to grow freshwater prawn and whitefish as polyculture in ponds or as integrated culture on their agricultural lands. Thus, in contrast to Mithakhali, the social-ecological system in Kamarkhola managed to reorganize and prevent the farming system from tipping over to a state that is undesirable for most farmers.

\section{Distributional effects on human well-being}

Material well-being

The material dimensions of well-being received comparatively greater attention than the other dimensions because income and food security were the most basic needs for survival. In Mithakhali, material well-being decreased for the majority of households (Fig. 4), particularly in the middle income and poor classes, because of dwindling profits from shrimp farming, inability to grow rice or fish for subsistence, and the need to purchase all grocery items from the market. Poor shrimp yields also led to a reduction in land rents and profits from shrimprelated businesses. The lack of agricultural activities within the village compelled wage laborers to migrate to nearby subdistricts, often agreeing to work for lower wages. The increased use of bamboo cages for harvesting shrimp also lowered the need for labor on large shrimp farms. In contrast, rich households reported 
improved well-being, particularly because of the accumulation of land over three decades, which allowed them to carry out largescale aquaculture and invest in high-return nonfarm activities. Similarly, households from other wealth classes mentioned good profits from shrimp or income from multiple sources as the main reasons for increased well-being.

Fig. 4. Changes in material well-being resulting from changes in farming systems in Mithakhali and Kamarkhola.

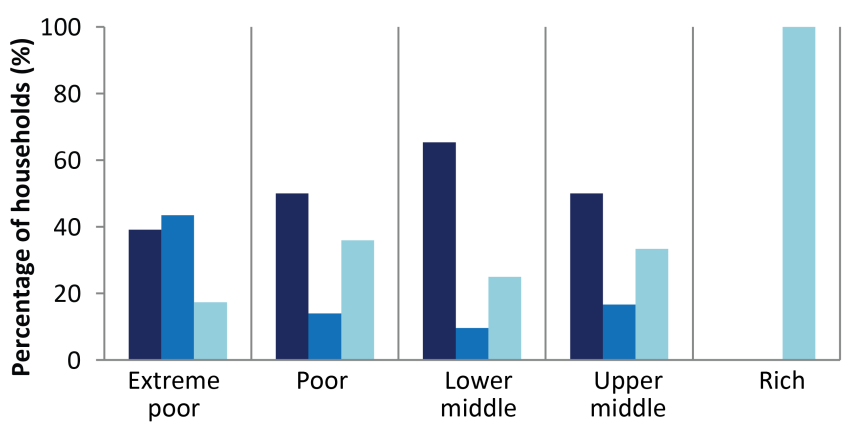

A. Mithakhali

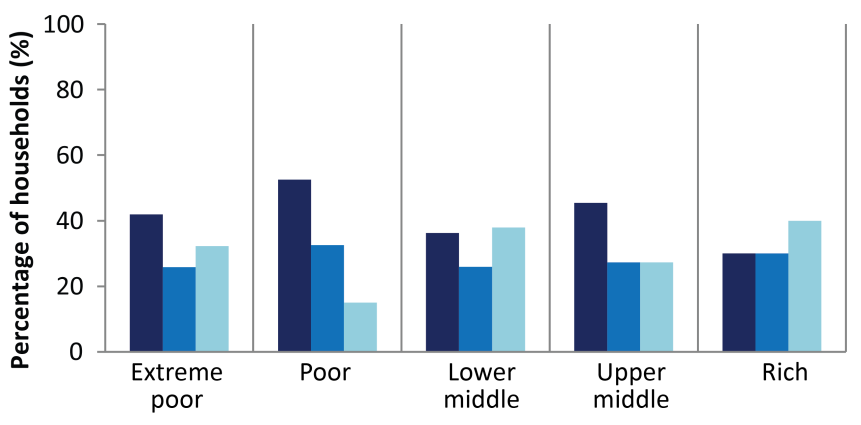

B. Kamarkhola

Worse-off than before

Same as before

Better-off than before

\begin{abstract}
The shrimp business has enabled my family, as well as many others, to escape from the poverty-stricken minimalistic rural lives. My father dropped out of primary school and worked as a medium-scale rice farmer during his 20 s and 30s. Later, shrimp farming allowed him to earn lots of money, which he spent to educate his children. Now my brother and I have good jobs in Khulna city, where we live with our families. We come to the village from time to time to supervise the managers who look after our shrimp farms. Upper middle class farmer, Mithakhali
\end{abstract}

In Kamarkhola, although the transition of the farming system was desirable for most people, many of them still considered themselves as being worse off than previously, particularly in the material dimension. This was mainly for three reasons. First, at the time of the study, it had been only three years since farming activities had resumed after cyclone Aila, and many households had not yet successfully started freshwater Galda prawn farming or livestock rearing on an economically beneficial scale. Second, although environmental quality was better, in the absence of shrimp disease outbreaks, the cash income from shrimp was much higher than that from rice. Third, households that were reliant on shrimp-related businesses were now solely reliant on other villages in the region.
During shrimp cultivation, millions of taka worth of goods would be carried along these rivers day and night. People had cash in their pockets, and they could purchase the goods they needed. Now it's difficult to get over that addiction to cash. I secretly farm shrimp in a small parcel of land outside the embankment. But there is no satisfaction in cultivating shrimps stealthily in such small amounts of land. Rich farmer, Kamarkhola.

However, the opportunity to pursue multiple livelihood activities such as agriculture, business, and service generated both marketand subsistence-oriented income, thus improving material wellbeing for some households. Poor and extreme poor farmers, who were previously dependent on wage labor only, had the opportunity to engage in sharecropping contracts with large farmers. In both villages, material well-being remained unchanged for some households because the increase in cash income was offset by rising expenditures to raise a family. Some poor and extreme poor families, who solely depended on physical labor and were not directly involved with farming, did not experience any significant changes, often saying, "We live hand to mouth; we were poor, and will always be poor."

\section{Relational well-being}

While the material dimension refers to what people have, the relational dimension reflects what people can do with what they have, thus emphasizing people's freedom to act in ways that correspond with their own interests and values. In Mithakhali, most farmers reported a loss of relational well-being because large landowners used their power to shift from a shrimp-paddy rotational system to year-long aquaculture-based livelihoods. This suffocated the agency of smallholding farmers by trapping them in an undesirable farming system. People's words, tone of voice, and facial expressions often reflected a sense of despair, injustice, and frustration. The lack of autonomy in choosing livelihood strategies, the need to adhere to existing rules of farming, and fears about long-term livelihood outcomes were evident in some narrations.

\section{Even if I want, I can never stop shrimp cultivation on my own. If other farmers adjacent to my land are doing so, I have to do it as well. Recently, due to the oil spillage in Sheila River near the Sundarbans, the government is thinking of creating an alternative route by dredging our nearby Passur River. But no matter how much they dredge, each high tide will bring tonnes of sediment and raise the river bed once again. The only solution is to stop shrimp farming and cut all the dykes along the farms so that the silt and clay can be deposited on the land during high tide. You must allow water exchange to occur in its natural way. If shrimp cultivation is stopped, the soil will start regaining its fertility in a year. Lower middle class farmer, Mithakhali.}

There was also a general lack of faith in institutions such as the national and local government and nongovernmental 
organizations, and a lack of trust among community members and different actors in the aquaculture supply chain. Farmers faced losses from both ends; increased disease outbreaks were reducing shrimp yields, and farmers sometimes failed to receive a good market price for their produce.

I used to collect drums of shrimp from the farms and sell them at the depots in Khulna. Now the shrimp yields have decreased and many more people are involved in this business, so there is no profit. All the farmers used to trust me with their shrimp because they knew that I would repay them in time. The people at the depots used to tell me that they never found a bad fish in the drums I supplied. Even today, when I go there, they hug me out of affection and respect. But nowadays, the middlemen are pushing gels and water into the shrimp to increase their weight and get more profits. But in the long run, the European countries are identifying these adulterations and are now showing reluctance to buy our shrimp. Lower middle class farmer, Mithakhali.

In contrast, some considered the change in farming a necessary transformation that enabled farmers to cope with the changing needs of society. Three decades previously, the population size was smaller, and competition for natural resources was limited. People could spend their entire lifetimes within the confines of their village, with food sufficiency being the only concern. However, a better life in the new millennium necessitates cash for pursuing education, accessing proper health care, and purchasing consumptive goods such as televisions and mobile phones. Thus, relational well-being improved because cash from shrimp farming provided freedom of choice.

In Kamarkhola, although material well-being remained unchanged or even worsened for some people, relational wellbeing improved significantly because people had the freedom to act in ways that were meaningful to them. People had confidence in the local government leader, who helped them take collective action against the outside entrepreneurs. However, they perceived nongovernmental organizations as profit-making organizations that ripped off the poor in the name of development. Nevertheless, many households relied on microcredit for investment in crops and fisheries. Well-being also involved living well together as a community, rather than pursuing one's own selfish motives.

Those who say that they were better off during the shrimp period are salt pirates! They are like predatory animals! Shrimp farming only benefitted 5 out of 100 people, while the poor and landless suffered from poverty. If they asked for some fish, they'd be beaten up by the farm owner. But now if a hungry person comes to my door asking for rice, he does not return empty handed. Lower middle class farmer, Kamarkhola.

\section{Subjective well-being}

Subjective well-being refers to what people think or feel about what they have or do. In rural Bangladesh, rice farming traditionally formed an integral aspect of cultural identity. There was pride and satisfaction in being recognized as a successful rice farmer. Large landowners often served as informal village leaders and supported smallholding farmers in times of need. In Mithakhali, the inability of grow rice and the general shift in the social structure led to a loss of subjective well-being.

We have been rice farmers for generations; we neither
understand nor can do anything other than rice. After the
harvest, my yard would be filled with piles of paddy, and
workers would be busy milling them. The paddy heaps
were so high that our children would climb them to see
the entire village. My homestead yard used to be filled
with large buffalos that were used for ploughing the land.
Now I have a couple of malnourished cows. Upper
middle class farmer, Mithakhali.

The opposite was true for most farmers in Kamarkhola; the farming system transformation led to better environmental quality and greater peace of mind. Vegetation cover and soil quality improved over time. Although some farmers reported losses in prawn yield because of disease outbreaks, freshwater prawn cultivation was relatively less risky.

During shrimp cultivation, the roads used to be so muddy all the time that if you walked along, your shirt would be spilled with mud. The air was very toxic, it felt as if we were inhaling chemicals. Now it feels great to have so many fruit trees around our house. Our children have something to eat. When a guest like you comes along we have something to offer. Upper middle class farmer, Kamarkhola.

\section{DISCUSSION AND CONCLUSION}

Social-ecological systems such as the aquaculture system studied here are complex adaptive systems in which actors with different values and interests interact with each other and their natural environment. Actors learn from their past experiences and use their accumulated knowledge to respond to challenges. The system is not governed by deterministic laws: as the system evolves, the rules of the game change (Darnhofer et al. 2010). Unpacking these complex chains of interactions, spanning from local to global scales, requires interdisciplinary approaches of scientific investigation; however, differences in epistemological origins and methodologies associated with different concepts often create cognitive challenges to capturing the breadth without sacrificing the depth (Stojanovic et al. 2016). Here, we sought to bridge these disciplinary divides by empirically demonstrating the combined application of resilience, political ecology, and wellbeing perspectives in understanding the drivers and distributional effects of social-ecological change in coastal Bangladesh.

The adaptive cycle heuristic offered a useful analytical framework to analyze the changes in system characteristics and behaviors and understand the multiple cross-scale interactions among several domains. Although the adaptive cycle may not be applicable to all complex systems (Cumming and Collier 2005), it has been particularly useful in analyzing changes in characteristics and behaviors of capture fisheries systems (Seixas and Berkes 2003, Goulden et al. 2013, Jacques 2015, Prado et al. 2015), with relatively limited application in culture fisheries systems (Garschagen 2010, Beymer-Farris et al. 2012). The evolution of the shrimp aquaculture system studied here closely adheres to the attributes of the different phases of the adaptive cycle model. The exploitation phase was characterized by 
plentiful natural resources and rapid growth of the aquaculture industry. Availability of fallow lands during the dry season, good soil productivity, and abundance of wild postlarvae enabled outside entrepreneurs to earn huge amounts of cash with minimal investment. New social hierarchies were formed as the traditional patron-client relationships among peasants were replaced by market-oriented cash crops. During the conservation phase, the growth rate slowed as land scarcity impeded further extensification of shrimp aquaculture, and productivity was increased by stocking hatchery-bred postlarvae in addition to wild ones. The system's potential and connectedness increased at the cost of decreasing resilience. Development of associated services such as hatcheries, depots, and processing plants expanded social networks along the supply chain, and the shrimp-paddy rotational system was institutionalized throughout the coastal region. Disease outbreaks on shrimp farms, declining paddy yields, and distributional injustices between outside entrepreneurs and local farmers triggered the release phase. The cohesive social structure became unstable, and contradictory coalitions of interests started to emerge. Whereas some farmers still favored the cash crop economy, others preferred to revert to the traditional subsistencebased farming system, thus forming new constellations of values in both villages. The farming systems in both villages transformed to a new state; however, local governance processes and power dynamics among farmers of different wealth classes determined whose desirable state was reached. During the reorganization phase, farmers drew upon their skills and knowledge to experiment with newer forms of livelihoods such as pond-based polyculture of freshwater prawn and whitefish (in Kamarkhola) and land-based farming of different marine and freshwater fish (in Mithakhali).

The resilience approach thus provided a system-oriented analysis of the changes in potential and connectedness within the social and ecological spheres without sufficiently engaging with the roles of power, interests, and agency in navigating change. Integration of a political ecology approach offered an actor-oriented perspective that proved to be essential in explaining the root causes of the different responses of the two villages. For instance, in Mithakhali, at the time of study, shrimp cultivation was carried out by large local landowners rather than by outside entrepreneurs, who were overthrown in the late 1990s. This made it difficult for local people to protest against shrimp farming because the large landowners had the rights to farm their own land as they pleased. The ability to gain profits from shrimp mainly depended on the capacity to own, lease, and control land; thus, large landowners with political connections and the financial resources necessary for investment turned out to be winners, whereas poor and landless farmers were pushed into further poverty (see also Abdullah et al. 2017). However, in Kamarkhola, shrimp cultivation was mostly carried out by outside entrepreneurs, making it comparatively easier for the local farmers to evict them in 2008, with the support of local political leaders and grassroots organizations. Moreover, in Mithakhali, outside entrepreneurs were evicted in the 1990s because local farmers wanted to cultivate shrimp on their own land and earn increased cash. At that time, the negative effects of shrimp cultivation on other livelihood sources were not apparent. However, in Kamarkhola, when local farmers protested against outside entrepreneurs in 2008 , they wanted to stop shrimp and revert to paddy because they were aware of the adverse consequences of brackish water shrimp farming.

In addition, in Kamarkhola, the presence of certain key elements of social resilience such as social memory, leadership, and crisis enabled the transition of the farming system to a more desirable state. During the 1990s, there were various kinds of local resistance in Khulna to the appropriation of public lands, coercive treatment of small-scale rice farmers reluctant to lease out their land, and flooding of paddy fields with saline water. Hence, the culture of social movements and dealing with crisis actively through collective action was embedded within the social memory of the local people (see also Beymer-Farris et al. 2012). As in previous social movements, the protests in Kamarkhola were supported by members of local political parties or nongovernmental organizations who played key roles in organizing local community members and helping them express their collective frustration against years of injustice. In this case, the local parliamentary member, in association with a couple of antisaline-water environmental protection groups, played a crucial role in mobilizing people and ultimately obtaining an order from the High Court that banned shrimp cultivation in the area. Finally, the destruction created by the cyclone opened up opportunities to start a new farming regime. Whereas farmers in Mithakhali were concerned about the immediate difficulties of stopping shrimp cultivation, those in Kamarkhola could depend on cyclone aid during the transition period.

Application of the social conception of well-being provided a nuanced understanding of the distributional effects of socialecological change on households of different classes. The empirical evidence showed that well-being was not only determined by economic gains, it also relied on people's freedom to act in ways that were consistent with their own values and aspirations, which were, in turn, shaped by their perceptions of the surrounding environment and understanding of what constitutes a good life. Rice cultivation was not just a job but a way of life; sufficiency in rice is an important aspect of well-being for most people in rural Bangladesh (see also White 2010). A recent study in coastal Bangladesh also noted that material gains from shrimp farming were offset by worsening subjective wellbeing caused by the loss of self-sufficiency in rice, frustration at injustices related to land expropriation, and despair about the future (Belton 2016). In contrast, freshwater prawn, fish, and paddy cultivation positively contributed to societal well-being by enabling both cash income and food security, creating more equitable distribution of resources, and by retaining a cultural identity as rice farmers (Belton 2016).

The integration of resilience, political ecology, and well-being approaches here thus helped to engage better with the social complexities of change and provided a more grounded analysis of what is desirable and for whom. Social-ecological systems research is often dominated by system-oriented approaches that tend to rely on quantitative measurements of linkages among various components. Factors and processes that do not fit within the boxes and arrows of the system model are sometimes ignored. For instance, in studying the interrelationships between ecosystem services and well-being in coastal Bangladesh, Hossain et al. (2016, 2017) used indicators such as percentage of population below the poverty line, gross domestic product, and production 
cost as measures of material well-being; education as a proxy for freedom of choice; and water and sanitation facilities, housing conditions, and birth by a skilled health trainer as measures of quality of life. Analysis of aggregate indicators at a regional level reflected strong positive relationships between provisioning services and material well-being, and weak relationships with regulating services. As argued by Dawson and Martin (2015), such reductionist approaches fail to acknowledge the conflicting objectives of different interest groups, the power relations, and trade-offs associated with changes in ecosystem services. Aggregate measures can lead to policies that seek to increase overall economic growth to promote human development. The adverse socioeconomic and agro-ecological impacts resulting from the unregulated growth of the shrimp industry in coastal Bangladesh is a living example of the dangers of such reductionist research approaches and policy formulation. Interdisciplinary approaches are essential for studying human-nature interactions; however, using social theories as addendums to established ecological frameworks can prove to be counterproductive. Methodological approaches should be tailored to capture the inner workings of human societies and heterogeneous needs of different people.

Responses to this article can be read online at: http://www.ecologyandsociety.org/issues/responses. $\mathrm{php} / 9422$

\section{Acknowledgments:}

This paper is part of a Doctoral dissertation funded by the Leeds International Research Scholarship (LIRS) and the Sustainability Research Institute (SRI) fieldwork bursary, University of Leeds, $U K$.

\section{LITERATURE CITED}

Abdullah, A. N., B. Myers, N. Stacey, K. K. Zander, and S. T. Garnett. 2016. The impact of the expansion of shrimp aquaculture on livelihoods in coastal Bangladesh. Environment, Development and Sustainability. http://dx.doi.org/10.1007/ $\underline{\text { s10668-016-9824-5 }}$

Adger, W. N. 2000. Social and ecological resilience: are they related? Progress in Human Geography 24(3):347-364. http://dx. doi.org/10.1191/030913200701540465

Armitage, D., C. Béné, A. T. Charles, D. Johnson, and E. H. Allison. 2012. The interplay of well-being and resilience in applying a social-ecological perspective. Ecology and Society 17 (4):15. http://dx.doi.org/10.5751/ES-04940-170415

Bachrach, P., and M. S. Baratz. 1962. Two faces of power. American Political Science Review 56(4):947-952. http://dx.doi. org/10.2307/1952796

Belton, B. 2016. Shrimp, prawn and the political economy of social wellbeing in rural Bangladesh. Journal of Rural Studies 45:230-242. http://dx.doi.org/10.1016/j.jrurstud.2016.03.014

Beymer-Farris, B. A., T. J. Bassett, and I. Bryceson. 2012. Promises and pitfalls of adaptive management in resilience thinking: the lens of political ecology. Pages 283-299 in T. Plieninger and C. Bieling, editors. Resilience and the cultural landscape: understanding and managing change in human-shaped environments. Cambridge University Press, Cambridge, UK.

Binder, C. R., J. Hinkel, P. W. G. Bots, and C. Pahl-Wostl. 2013. Comparison of frameworks for analyzing social-ecological systems. Ecology and Society 18(4):26. http://dx.doi.org/10.5751/ ES-05551-180426

Boonstra, W. J. 2016. Conceptualizing power to study socialecological interactions. Ecology and Society 21(1):21. http://dx. doi.org/10.5751/ES-07966-210121

Brown, K. 2016. Resilience, development and global change. Routledge, London, UK.

Bryant, R. L. 1998. Power, knowledge and political ecology in the third world: a review. Progress in Physical Geography 22(1):79-94. http://dx.doi.org/10.1177/030913339802200104

Copestake, J. 2008. Wellbeing in international development: What's new? Journal of International Development 20(5):577-597. http://dx.doi.org/10.1002/jid.1431

Cote, M., and A. J. Nightingale. 2012. Resilience thinking meets social theory: situating social change in socio-ecological systems (SES) research. Progress in Human Geography 36(4):475-489. http://dx.doi.org/10.1177/0309132511425708

Coulthard, S. 2012. Can we be both resilient and well, and what choices do people have? Incorporating agency into the resilience debate from a fisheries perspective. Ecology and Society 17(1):4. http://dx.doi.org/10.5751/ES-04483-170104

Coulthard, S., D. Johnson, and J. A. McGregor. 2011. Poverty, sustainability and human wellbeing: a social wellbeing approach to the global fisheries crisis. Global Environmental Change 21 (2):453-463. http://dx.doi.org/10.1016/j.gloenvcha.2011.01.003

Cumming, G. S., and J. Collier. 2005. Change and identity in complex systems. Ecology and Society 10(1):29. http://www. ecologyandsociety.org/vol10/iss1/art29/

Cutter, S. L., L. Barnes, M. Berry, C. Burton, E. Evans, E. Tate, and J. Webb. 2008. A place-based model for understanding community resilience to natural disasters. Global Environmental Change 18(4):598-606. http://dx.doi.org/10.1016/j.gloenvcha.2008.07.013

Dahl, R. A. 1957. The concept of power. Systems Research and Behavioral Science 2(3):201-215. http://dx.doi.org/10.1002/ $\underline{\text { bs.3830020303 }}$

Darnhofer, I., J. Fairweather, and H. Moller. 2010. Assessing a farm's sustainability: insights from resilience thinking. International Journal of Agricultural Sustainability 8(3):186-198. http://dx.doi.org/10.3763/ijas.2010.0480

Davoudi, S. 2012. Resilience: a bridging concept or a dead end? Planning Theory and Practice 13(2):299-307. http://dx.doi. org/10.1080/14649357.2012.677124

Daw, T., K. Brown, S. Rosendo, and R. Pomeroy. 2011. Applying the ecosystem services concept to poverty alleviation: the need to disaggregate human well-being. Environmental Conservation 38 (4):370-379. http://dx.doi.org/10.1017/S0376892911000506 
Daw, T. M., S. Coulthard, W. W. L. Cheung, K. Brown, C. Abunge, D. Galafassi, G. D. Peterson, T. R. McClanahan, J. O. Omukoto, and L. Munyi. 2015. Evaluating taboo trade-offs in ecosystems services and human well-being. Proceedings of the National Academy of Sciences 112(22):6949-6954. http://dx.doi.org/10.1073/ pnas. 1414900112

Dawson, N., and A. Martin. 2015. Assessing the contribution of ecosystem services to human wellbeing: a disaggregated study in western Rwanda. Ecological Economics 117:62-72. http://dx.doi. org/10.1016/j.ecolecon.2015.06.018

Disaster Management Bureau. 2010. National plan for disaster management 2010-2015. Disaster Management Bureau, Dhaka, Bangladesh. [online] URL: http://www.bd.undp.org/content/ bangladesh/en/home/library/crisis_prevention_and_recovery/nationalplan-for-disaster-management-2010-2015.html

Fabinyi, M., L. Evans, and S. J. Foale. 2014. Social-ecological systems, social diversity, and power: insights from anthropology and political ecology. Ecology and Society 19(4):28. http://dx.doi. org/10.5751/ES-07029-190428

Folke, C. 2006. Resilience: the emergence of a perspective for social-ecological systems analyzes. Global Environmental Change 16(3):253-267. http://dx.doi.org/10.1016/j.gloenvcha.2006.04.002

Garschagen, M. 2010. Crises prevention and climate change adaptation in the coupled social-ecological systems of the Mekong Delta, Vietnam: the need for rethinking concepts and policies. United Nations University Institute for Environment and Human Security (UNU-EHS), Bonn, Germany.

Goulden, M. C., W. N. Adger, E. H. Allison, and D. Conway. 2013. Limits to resilience from livelihood diversification and social capital in lake social-ecological systems. Annals of the Association of American Geographers 103(4):906-924. http://dx. doi.org/10.1080/00045608.2013.765771

Gunderson, L. H., and C. S. Holling, editors. 2002. Panarchy: understanding transformations in human and natural systems. Island Press, Washington, D.C., USA.

Holling, C. S. 1986. The resilience of terrestrial ecosystems: local surprise and global change. Pages 292-317 in W. C. Clark and R. E. Munn, editors. Sustainable development of the biosphere: interactions between the world economy and the global environment. Cambridge University Press, Cambridge, UK.

Holling, C. S. 2001. Understanding the complexity of economic, ecological, and social systems. Ecosystems 4(5):390-405. http:// dx.doi.org/10.1007/s10021-001-0101-5

Hossain, M. S., J. A. Dearing, M. M. Rahman, and M. Salehin. 2016. Recent changes in ecosystem services and human well-being in the Bangladesh coastal zone. Regional Environmental Change 16(2):429-443. http://dx.doi.org/10.1007/s10113-014-0748-Z

Hossain, M. S., F. Eigenbrod, F. Amoako Johnson, and J. A. Dearing. 2017. Unravelling the interrelationships between ecosystem services and human wellbeing in the Bangladesh delta. International Journal of Sustainable Development and World Ecology 24(2):120-134. http://dx.doi.org/10.1080/13504509.2016.1182087

Huq, N., J. Hugé, E. Boon, and A. K. Gain. 2015. Climate change impacts in agricultural communities in rural areas of coastal
Bangladesh: a tale of many stories. Sustainability 7(7):8437-8460. http://dx.doi.org/10.3390/su7078437

Ingalls, M. L., and R. C. Stedman. 2016. The power problematic: exploring the uncertain terrains of political ecology and the resilience framework. Ecology and Society 21(1):6. http://dx.doi. org/10.5751/ES-08124-210106

Jacques, P. J. 2015. Are world fisheries a global panarchy? Marine Policy 53:165-170. http://dx.doi.org/10.1016/j.marpol.2014.11.024

Janssen, M. A., M. L. Schoon, W. Ke, and K. Börner. 2006. Scholarly networks on resilience, vulnerability and adaptation within the human dimensions of global environmental change. Global Environmental Change 16(3):240-252. http://dx.doi. org/10.1016/j.gloenvcha.2006.04.001

Leach, M., editor. 2008. Re-framing resilience: a symposium report. STEPS working paper 13. STEPS Centre, Brighton, UK. [online] URL: http://steps-centre.org/wp-content/uploads/Resilience. pdf

Lukes, S. 1974. Power: a radical view. First edition. Macmillan, London, UK.

Mahmuduzzaman, M., Z. U. Ahmed, A. K. M. Nuruzzaman, and F. R. S. Ahmed. 2014. Causes of salinity intrusion in coastal belt of Bangladesh. International Journal of Plant Research 4 (4A):8-13. http://dx.doi.org/10.5923/s.plant.201401.02

Marschke, M. J., and F. Berkes. 2006. Exploring strategies that build livelihood resilience: a case from Cambodia. Ecology and Society 11(1):42. [online] URL: http://www.ecologyandsociety. org/vol11/iss $1 /$ art42/

McGinnis, M. D., and E. Ostrom. 2014. Social-ecological system framework: initial changes and continuing challenges. Ecology and Society 19(2):30. http://dx.doi.org/10.5751/ES-06387-190230

McGregor, J. A. 2007. Researching human wellbeing: from concepts to methodology. Pages 316-350 in I. Gough and J. A. McGregor, editors. Wellbeing in developing countries: from theory to research. Cambridge University Press, Cambridge, UK.

Miller, F., H. Osbahr, E. Boyd, F. Thomalla, S. Bharwani, G. Ziervogel, B. Walker, J. Birkmann, S. van der Leeuw, J. Rockström, J. Hinkel, T. Downing, C. Folke, and D. Nelson. 2010. Resilience and vulnerability: complementary or conflicting concepts? Ecology and Society 15(3):11. http://www.ecologyandsociety.org/ vol15/iss3/art11/

Ministry of Environment and Forests. 2009. Bangladesh climate change strategy and action plan 2009. Ministry of Environment and Forests, Government of Bangladesh, Dhaka, Bangladesh. [online] URL: https://www.iucn.org/content/bangladesh-climatechange-strategy-and-action-plan-2009

Moshy, V. H., I. Bryceson, and R. Mwaipopo. 2015. Socialecological changes, livelihoods and resilience among fishing communities in Mafia Island Marine Park, Tanzania. Forum for Development Studies 42(3):529-553. http://dx.doi. org/10.1080/08039410.2015.1065906

Nuruzzaman, M. 2006. Dynamics and diversity of shrimp farming in Bangladesh: technical aspects. Pages 431-460 in A. A. Rahman, A. H. G. Quddus, B. Pokrant, and M. L. Ali, editors. 
Shrimp farming and industry: sustainability, trade and livelihoods. University Press and Bangladesh Centre for Advanced Studies (BCAS), Dhaka, Bangladesh.

Olsson, P., V. Galaz, and W. J. Boonstra. 2014. Sustainability transformations: a resilience perspective. Ecology and Society 19 (4):1. http://dx.doi.org/10.5751/ES-06799-190401

Orchard, S. E., L. C. Stringer, and C. H. Quinn. 2016. Mangrove system dynamics in Southeast Asia: linking livelihoods and ecosystem services in Vietnam. Regional Environmental Change 16(3):865-879. http://dx.doi.org/10.1007/s10113-015-0802-5

Peet, R., and M. Watts, editors. 1996. Liberation ecologies: environment, development, social movements. Routledge, London, UK.

Peterson, G. 2000. Political ecology and ecological resilience: an integration of human and ecological dynamics. Ecological Economics 35(3):323-336. http://dx.doi.org/10.1016/S0921-8009 (00)00217-2

Pokrant, B. 2014. Brackish water shrimp farming and the growth of aquatic monocultures in coastal Bangladesh. Pages 107-132 in J. Christensen and M. Tull, editors. Historical perspectives of fisheries exploitation in the Indo-Pacific. Springer, Dordrecht, The Netherlands.

Prado, D. S., C. S. Seixas, and F. Berkes. 2015. Looking back and looking forward: exploring livelihood change and resilience building in a Brazilian coastal community. Ocean and Coastal Management 113:29-37. http://dx.doi.org/10.1016/j.

ocecoaman.2015.05.018

Seixas, C. S., and F. Berkes. 2003. Dynamics of social-ecological changes in a lagoon fishery in southern Brazil. Pages 271-298 in F. Berkes, J. Colding, and C. Folke, editors. Navigating socialecological systems: building resilience for complexity and change. Cambridge University Press, Cambridge, UK.

Shameem, M. I. M., S. Momtaz, and R. Rauscher. 2014. Vulnerability of rural livelihoods to multiple stressors: a case study from the southwest coastal region of Bangladesh. Ocean and Coastal Management 102(A):79-87. http://dx.doi.org/10.1016/ j.ocecoaman.2014.09.002

Speranza, C. I., U. Wiesmann, and S. Rist. 2014. An indicator framework for assessing livelihood resilience in the context of social-ecological dynamics. Global Environmental Change 28:109-119. http://dx.doi.org/10.1016/j.gloenvcha.2014.06.005

Stojanovic, T., H. M. McNae, P. Tett, T. W. Potts, J. Reis, H. D. Smith, and I. Dillingham. 2016. The "social" aspect of socialecological systems: a critique of analytical frameworks and findings from a multisite study of coastal sustainability. Ecology and Society 21(3):15. http://dx.doi.org/10.5751/ES-08633-210315

Tucker, J., M. Daoud, N. Oates, R. Few, D. Conway, S. Mtisi, and S. Matheson. 2015. Social vulnerability in three high-poverty climate change hot spots: What does the climate change literature tell us? Regional Environmental Change 15(5):783-800. http://dx. doi.org/10.1007/s10113-014-0741-6

Turner, M. D. 2013. Political ecology I: an alliance with resilience? Progress in Human Geography 38(4):616-628. http://dx.doi. org/10.1177/0309132513502770
Walker, B., C. S. Holling, S. R. Carpenter, and A. Kinzig. 2004. Resilience, adaptability and transformability in social-ecological systems. Ecology and Society 9(2):5. http://www.ecologyandsociety. org/vol9/iss2/art5/

Walker, B., and D. Salt. 2006. Resilience thinking: sustaining ecosystems and people in a changing world. Island Press, Washington, D.C., USA.

Weber, M. 1947. The theory of social and economic organization. Free Press, New York, New York, USA.

Wellbeing in Developing Countries Research. 2007. Wellbeing and international development. ESRC Research Group on Wellbeing in Developing Countries, University of Bath, Bath, UK. [online] URL: http://www.welldev.org.uk/research/aims.htm

White, S. C. 2010. analyzing wellbeing: a framework for development practice. Development in Practice 20(2):158-172. http://dx.doi.org/10.1080/09614520903564199 
Table A1.1 Characteristics used for wealth stratification using participatory wealth ranking

\begin{tabular}{|c|c|c|}
\hline \multirow{2}{*}{$\begin{array}{l}\text { Wealth } \\
\text { category }\end{array}$} & \multicolumn{2}{|c|}{ Characteristics outlined by respondents } \\
\hline & Kamarkhola & Mithakhali \\
\hline Rich & $\begin{array}{l}\text { - Owns }>3.4 \text { hectares of agricultural land (About } 5 \text { having }>20 \\
\text { - } \text { hectares) } \\
\text { - } \text { land to sharecroppers; some engaged in service sector } \\
\text { - } \text { Mainly inherited property } \\
\text { - } \text { Some reside outside the village in nearby towns or cities } \\
\text { - } \quad \text { Usually have brick houses, motorcycles, TV and good furniture } \\
\text { - } \quad \text { Union council leader or village chairman are usually from this } \\
\text { - Have good amount of savings, may take loans from banks for ir } \\
\text { - Never face food shortage }\end{array}$ & $\begin{array}{l}\text { - Owns }>5.4 \text { hectares of agricultural land } \\
\text { - Owners of large shrimp farms, often including land leased } \\
\text { in from smaller farmers; also engaged in aquaculture } \\
\text { related businesses } \\
\text { - Some are rich for generations, while others have } \\
\text { purchased land in last three decades } \\
\text { class } \\
\text { tvestments }\end{array}$ \\
\hline $\begin{array}{l}\text { Upper } \\
\text { middle }\end{array}$ & $\begin{array}{l}\text { - } \text { Owns between } 1.3 \text { and } 3.4 \text { hectares of agricultural land } \\
\text { - } \quad \text { Engaged in crop cultivation, as well as moderate scale Galda } \\
\text { prawn/ white fish farming. } \\
\text { - } \quad \text { Durable housing with brick/mud walls and floors and tin roofs } \\
\text { - } \quad \text { Children pursuing tertiary education outside village } \\
\text { - Have moderate amount of savings } \\
\text { - } \quad \text { Never face food shortage }\end{array}$ & $\begin{array}{l}\text { - Owns between } 2.7 \text { and } 5.4 \text { hectares of agricultural land } \\
\text { - Owners of medium shrimp farms, either independently or } \\
\text { with land leased in from others; some involved in service } \\
\text { sector }\end{array}$ \\
\hline $\begin{array}{l}\text { Lower } \\
\text { middle }\end{array}$ & $\begin{array}{l}\text { - } \text { Owns between } 0.4 \text { and } 1.3 \text { hectares of agricultural land } \\
\text { - Engaged in crop cultivation, as well as small scale Galda } \\
\text { prawn/ white fish farming; some involved in small } \\
\text { businesses/service sector } \\
\text { - Kacha houses with mud floors, mud/bamboo walls and tin/strav } \\
\text { - Have sufficiency of rice, but can afford protein only few times } \\
\text { - Income same as expenditures; hence, no savings }\end{array}$ & $\begin{array}{l}\text { - Owns between } 0.8 \text { and } 2.7 \text { hectares of agricultural land } \\
\text { - Owners of small shrimp farms, either independently or } \\
\text { under co-operative system; some involved in small } \\
\text { businesses } \\
v \text { roofs } \\
\text { a week }\end{array}$ \\
\hline Poor & $\begin{array}{ll}\text { - } & \text { Owns }<0.4 \text { hectares of agricultural land } \\
\text { - } & \text { Engaged in crop cultivation and wage laboring. }\end{array}$ & $\begin{array}{l}\text { - Owns }<0.8 \text { hectares of agricultural land } \\
\text { - Mainly lease out land or engage in co-operative farming; } \\
\text { many engaged in petty trades and/or wage laboring }\end{array}$ \\
\hline
\end{tabular}


- Kacha houses with mud floors, mud/bamboo walls and leaf/straw roofs

- Can afford two meals a day, with occasional protein intake

- Income usually not enough to meet household expenses; often have loans from NGOs

Extreme

Poor
- Do not have any agricultural land, many residing on the embankment

- Mainly dependent on wage laboring; some engaged in sharecropping.

- Poor housing with mud floors and walls/roofs made of palm leaves/straw

- Always face food shortage, hardly can afford protein items

- Income not enough to meet household expenses; often have loans from NGOs

Table A1.2 Results of wealth stratification using principal component and cluster analysis

\begin{tabular}{lcc}
\hline & Kamarkhola & Mithakhali \\
\hline Number of factors with eigenvalue $>1$ & 5 & 5 \\
\hline Variance explained (\%) by factors extracted & 62.1 & 62.1 \\
\hline KMO measures of sampling adequacy & 0.820 & 0.762 \\
\hline \multicolumn{3}{c}{ Number (\%) of households in each wealth class (n=150) } \\
\hline Rich & $10(6.7 \%)$ & $8(5.3 \%)$ \\
\hline Upper middle & $11(4.3 \%)$ & $17(12 \%)$ \\
\hline Lower middle & $58(38.7 \%)$ & $51(34 \%)$ \\
\hline Poor & $40(26.7 \%)$ & $49(32.7 \%)$ \\
\hline Extreme poor & $31(20.7 \%)$ & $25(16.7 \%)$ \\
\hline
\end{tabular}


Table A1.3 Descriptive statistics for 17 indicators in Kamarkhola and Mithakhali

\begin{tabular}{|c|c|c|c|c|c|c|c|c|c|c|}
\hline \multirow[t]{2}{*}{ Dimensions } & \multirow[t]{2}{*}{ Variables } & \multirow{2}{*}{$\begin{array}{l}\text { Type of } \\
\text { variable }\end{array}$} & \multicolumn{4}{|c|}{ Kamarkhola } & \multicolumn{4}{|l|}{ Mithakhali } \\
\hline & & & Minimum & Maximum & Mean & Variance & Minimum & Maximum & Mean & Variance \\
\hline \multirow{4}{*}{ Housing } & Wall material & Ordinal & 1 & 5 & 3.11 & 2.05 & 1 & 5 & 3.47 & 0.88 \\
\hline & Roof material & Ordinal & 1 & 4 & 2.47 & 1.31 & 1 & 4 & 2.71 & 0.63 \\
\hline & Floor material & Ordinal & 1 & 3 & 1.34 & 0.56 & 1 & 3 & 1.19 & 0.34 \\
\hline & No. of rooms & Scale & 1 & 7 & 2.61 & 1.14 & 2 & 8 & 3.88 & 1.36 \\
\hline \multirow[t]{5}{*}{$\begin{array}{l}\text { Consumptive } \\
\text { assets }\end{array}$} & $\begin{array}{l}\text { No. of furniture } \\
\text { items }\end{array}$ & Scale & 0 & 20 & 5.31 & 17.3 & 3 & 26 & 10.1 & 14.4 \\
\hline & No. of TV & Scale & 0 & 1 & 0.36 & 0.23 & 0 & 1 & 0.44 & 0.25 \\
\hline & $\begin{array}{l}\text { No. of Radio/CD } \\
\text { player }\end{array}$ & Scale & 0 & 1 & 0.13 & 0.12 & 0 & 1 & 0.04 & 0.04 \\
\hline & $\begin{array}{l}\text { No. of mobile } \\
\text { phones }\end{array}$ & Scale & 0 & 5 & 1.61 & 0.91 & 0 & 5 & 2.11 & 1.08 \\
\hline & $\begin{array}{l}\text { No. of } \\
\text { motorcycles }\end{array}$ & Scale & 0 & 1 & 0.07 & 0.07 & 0 & 1 & 0.07 & 0.07 \\
\hline \multirow{2}{*}{$\begin{array}{l}\text { Productive } \\
\text { assets }\end{array}$} & No. of fishing nets & Scale & 0 & 8 & 1.22 & 1.13 & 0 & 20 & 2.51 & 6.71 \\
\hline & No. of tools & Scale & 0 & 12 & 3.41 & 4.87 & 0 & 10 & 4.26 & 4.30 \\
\hline \multirow[t]{2}{*}{ Livestock } & $\begin{array}{l}\text { No. of } \\
\text { cows/buffalos }\end{array}$ & Scale & 0 & 15 & 2.04 & 5.81 & 0 & 10 & 0.57 & 2.41 \\
\hline & $\begin{array}{l}\text { No. of } \\
\text { goats/sheep }\end{array}$ & Scale & 0 & 5 & 0.41 & 1.25 & 0 & 20 & 1.14 & 7.26 \\
\hline $\begin{array}{l}\text { Agricultural } \\
\text { land }\end{array}$ & $\begin{array}{l}\text { Amount of } \\
\text { agricultural land } \\
\left(\text { decimals }^{1}\right)\end{array}$ & Scale & 0 & 2310 & 248 & 174096 & 0 & 3960 & 373 & 262484 \\
\hline \multirow[t]{2}{*}{$\begin{array}{l}\text { Homestead } \\
\text { Area }\end{array}$} & $\begin{array}{l}\text { Amount of } \\
\text { homestead land } \\
\text { (decimals) }\end{array}$ & Scale & 0 & 247 & 20.8 & 645 & 0 & 264 & 36.6 & 1937 \\
\hline & $\begin{array}{l}\text { Area of pond } \\
\text { (decimals) }\end{array}$ & Scale & 0 & 165 & 10.5 & 400 & 0 & 200 & 11.1 & 462 \\
\hline Education & $\begin{array}{l}\text { Percentage of } \\
\text { adult with SSC } \\
\text { degree or above }\end{array}$ & Scale & 0 & 100 & 39.1 & 1299 & 0 & 100 & 22.8 & 625 \\
\hline
\end{tabular}

\footnotetext{
${ }^{1} 1$ hectare $=247$ decimals
} 
Table A1.4 Factor loadings of the first principal component (weightages) of the 17 indicators in Kamarkhola and Mithakhali

\begin{tabular}{llcc}
\hline Dimensions & Variables & Kamarkhola & Mithakhali \\
\hline \multirow{2}{*}{ Housing } & Wall material & 0.69 & 0.56 \\
\cline { 2 - 4 } & Roof material & 0.70 & 0.55 \\
\cline { 2 - 4 } & Floor material & 0.60 & 0.52 \\
\cline { 2 - 4 } & No. of rooms & 0.78 & 0.71 \\
\hline \multirow{2}{*}{ Consumptive assets } & No. of furniture items & 0.81 & 0.80 \\
\cline { 2 - 4 } & No. of TV & 0.40 & 0.40 \\
\cline { 2 - 4 } & No. of Radio/CD player & 0.26 & 0.24 \\
\cline { 2 - 4 } & No. of mobile phones & 0.59 & 0.66 \\
\cline { 2 - 4 } & No. of motorcycles & 0.56 & 0.42 \\
\hline Productive assets & No. of fishing nets & 0.36 & 0.45 \\
\cline { 2 - 4 } & No. of tools & 0.54 & 0.32 \\
\hline Livestock & No. of cows/buffalos & 0.54 & 0.32 \\
\cline { 2 - 4 } & No. of goats/sheep & -0.13 & 0.36 \\
\hline Agricultural land & Amount of agricultural land & 0.80 & 0.78 \\
\hline Homestead Area & Amount of homestead land & 0.61 & 0.71 \\
\cline { 2 - 4 } & Area of pond & 0.26 & 0.39 \\
\hline Education & Percentage of adult with SSC degree & 0.39 & 0.43 \\
\hline
\end{tabular}


Table A1.5 Mean ownership of assets by wealth class in Kamarkhola

\begin{tabular}{|c|c|c|c|c|c|c|}
\hline Dimensions & Indicators & $\begin{array}{c}\text { Extreme } \\
\text { poor }(n=31)\end{array}$ & Poor $(n=40)$ & $\begin{array}{l}\text { Lower } \\
\text { middle } \\
(n=58)\end{array}$ & $\begin{array}{l}\text { Upper } \\
\text { middle } \\
(n=11)\end{array}$ & $\operatorname{Rich}(n=10)$ \\
\hline \multirow{4}{*}{ Housing } & $\begin{array}{l}\text { Wall material } \\
(1=\text { Leaves/straw/ cardboard/ plastic, } 2= \\
\text { Jute/bamboo, } 3=\text { Mud or unfired brick, } 4=\text { Tin/ } \\
\text { corrugated iron, } 5=\text { Concrete/ brick })\end{array}$ & 2.23 & 2.75 & 3.29 & 4.36 & 4.90 \\
\hline & $\begin{array}{l}\text { Roof material } \\
(1=\text { Leaves/straw/ cardboard, } 2 \text { = Tin/ corrugated } \\
\text { iron, } 3=\text { Concrete/ brick })\end{array}$ & 1.53 & 1.58 & 1.84 & 2.36 & 3.00 \\
\hline & $\begin{array}{l}\text { Floor material } \\
(1=\text { Mud or unfired brick, } 2 \text { = Wood, } 3=\text { Concrete/ } \\
\text { brick })\end{array}$ & 1.13 & 1.18 & 1.21 & 1.91 & 2.80 \\
\hline & No. of rooms & 1.97 & 2.13 & 2.76 & 3.73 & 4.40 \\
\hline \multirow{5}{*}{$\begin{array}{l}\text { Consumptive } \\
\text { assets }\end{array}$} & No. of furniture items & 3.23 & 2.88 & 5.74 & 11.5 & 12.2 \\
\hline & No. of TV & 0.13 & 0.33 & 0.41 & 0.45 & 0.80 \\
\hline & No. of Radio/CD player & 0.10 & 0.08 & 0.16 & 0.09 & 0.40 \\
\hline & No. of mobile phones & 1.10 & 1.35 & 1.74 & 2.64 & 2.30 \\
\hline & No. of motorcycles & 0.00 & 0.00 & 0.07 & 0.18 & 0.50 \\
\hline \multirow{2}{*}{$\begin{array}{l}\text { Productive } \\
\text { assets }\end{array}$} & No. of fishing nets & 1.00 & 1.05 & 1.22 & 1.82 & 1.90 \\
\hline & No. of tools & 2.94 & 2.55 & 3.64 & 5.64 & 4.50 \\
\hline $\begin{array}{l}\text { Agricultural } \\
\text { land }\end{array}$ & Amount of agricultural land (decimals) & 0.13 & 57.8 & 220 & 597 & 1554 \\
\hline \multirow{2}{*}{$\begin{array}{l}\text { Homestead } \\
\text { area }\end{array}$} & Amount of homestead land (decimals) & 6.87 & 11.48 & 22.69 & 43.55 & 65.50 \\
\hline & Area of pond (decimals) & 7.74 & 4.53 & 11.7 & 21.5 & 23.8 \\
\hline \multirow{2}{*}{ Livestock } & No. of cows/buffalos & 0.74 & 1.40 & 2.26 & 4.82 & 4.30 \\
\hline & No. of goats/sheep & 0.35 & 0.45 & 0.57 & 0.00 & 0.00 \\
\hline Education & Percentage of adult with SSC degree or above & 15.8 & 35.0 & 46.1 & 63.6 & 60.0 \\
\hline
\end{tabular}


Table A1.6 Mean ownership of assets by wealth class in Mithakhali

\begin{tabular}{|c|c|c|c|c|c|c|}
\hline Dimensions & Indicators & $\begin{array}{c}\text { Extreme } \\
\text { poor }(n=25)\end{array}$ & Poor $(n=49)$ & $\begin{array}{l}\text { Lower } \\
\text { middle } \\
(n=51)\end{array}$ & $\begin{array}{l}\text { Upper } \\
\text { middle } \\
(n=17)\end{array}$ & Rich (n=8) \\
\hline \multirow{4}{*}{ Housing } & $\begin{array}{l}\text { Wall material } \\
(1=\text { Leaves/straw/ cardboard/ plastic, } 2= \\
\text { Jute/bamboo, } 3=\text { Mud or unfired brick, } 4=\text { Tin/ } \\
\text { corrugated iron, } 5=\text { Concrete/ brick })\end{array}$ & 3.04 & 3.38 & 3.50 & 3.89 & 4.29 \\
\hline & $\begin{array}{l}\text { Roof material } \\
(1=\text { Leaves/straw/ cardboard, } 2 \text { = Tin/ corrugated } \\
\text { iron, } 3 \text { = Concrete/ brick) }\end{array}$ & 1.52 & 1.88 & 1.92 & 1.94 & 2.43 \\
\hline & $\begin{array}{l}\text { Floor material } \\
(1=\text { Mud or unfired brick, } 2 \text { = Wood, } 3=\text { Concrete/ } \\
\text { brick })\end{array}$ & 1.04 & 1.12 & 1.15 & 1.33 & 2.14 \\
\hline & No. of rooms & 3.04 & 3.94 & 3.73 & 4.33 & 6.14 \\
\hline \multirow{5}{*}{$\begin{array}{l}\text { Consumptive } \\
\text { assets }\end{array}$} & No. of furniture items & 7.52 & 9.78 & 9.58 & 12.6 & 18.1 \\
\hline & No. of TV & 0.13 & 0.34 & 0.50 & 0.72 & 1.00 \\
\hline & No. of Radio/CD player & 0.04 & 0.02 & 0.04 & 0.00 & 0.29 \\
\hline & No. of mobile phones & 1.35 & 2.12 & 2.13 & 2.33 & 3.71 \\
\hline & No. of motorcycles & 0.00 & 0.04 & 0.04 & 0.22 & 0.43 \\
\hline \multirow{2}{*}{$\begin{array}{l}\text { Productive } \\
\text { assets }\end{array}$} & No. of fishing nets & 1.13 & 2.08 & 2.37 & 4.44 & 6.14 \\
\hline & No. of tools & 3.57 & 4.24 & 4.19 & 5.17 & 4.86 \\
\hline $\begin{array}{l}\text { Agricultural } \\
\text { land }\end{array}$ & Amount of agricultural land (decimals) & 4.22 & 143 & 378 & 736 & 2253 \\
\hline \multirow{2}{*}{$\begin{array}{l}\text { Homestead } \\
\text { area }\end{array}$} & Amount of homestead land (decimals) & 5.48 & 28.9 & 32.5 & 65.9 & 149 \\
\hline & Area of pond (decimals) & 3.30 & 10.7 & 9.8 & 13.7 & 42.9 \\
\hline \multirow{2}{*}{ Livestock } & No. of cows/buffalos & 0.00 & 0.76 & 0.31 & 1.00 & 1.86 \\
\hline & No. of goats/sheep & 0.39 & 1.60 & 0.56 & 0.83 & 5.43 \\
\hline Education & Percentage of adult with SSC degree or above & 8.39 & 20.1 & 26.4 & 29.3 & 46.7 \\
\hline
\end{tabular}


Table A1.7 Characteristics used for structuring and analyzing data in relation to the adaptive cycle Characteristics of a SES in terms of its potential and connectedness

- Abundance of resources, allowing competition among Characteristics of the shrimp industry as identified from alternative social or ecological groups and formation of new empirical evidence

- Availability of fallow land during the dry season;

System exhibits flexibility and high resilience

- Abundance and diversity of post-larvae and fish juveniles in tidal water;

- Adoption of export-oriented growth policy, creating demand for market-based products

- Traditional patron-client peasant societies being replaced by commercial aquaculture

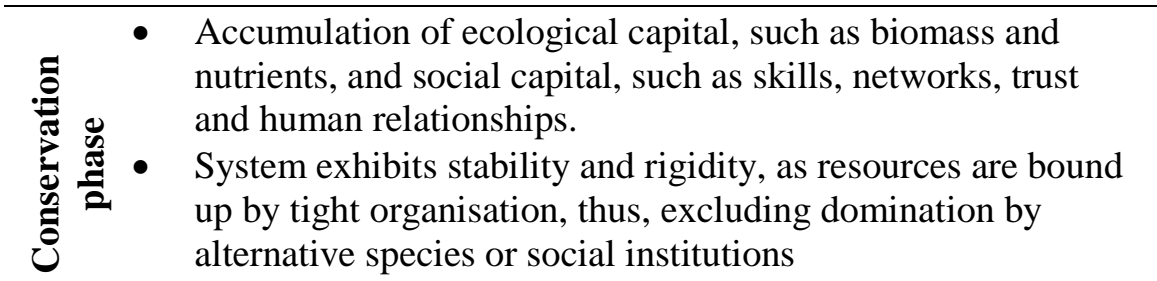

- $\quad$ Release of accumulated capital and collapse of system ฆ

• Social capital and behavior can break away from normalised routines and positions.

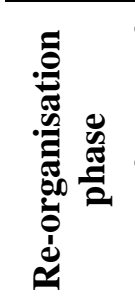

- High levels of financial investments by the government as well as large local farmers;

- Development of ancillary services along the supply, creating employment and trade networks

- Shrimp cultivation became the dominant livelihood activity, occupying private farmland, mangrove forests, public land and waterbodies

- Increased salinity leading to adverse impacts on subsistence based livelihood activities; Disease outbreaks in shrimp farms;

- $\quad$ Reluctance to continue brackish water shrimp farming and social movements against outside entrepreneurs;

- Occurrence of severe cyclones and tidal surges

- $\quad$ Skills acquired from brackish water shrimp cultivation used to experiment with white fish or freshwater prawn cultivation

- Destruction by cyclone Aila providing opportunity for changes in farming systems

- Difference in perceptions on brackish water shrimp cultivation; recognition of the ecological and economic potential for integrated freshwater prawn and paddy farming 